\title{
THE LONG WAY TO BILINGUALISM: THE PECULIAR CASE OF MULTILINGUAL SOUTH TYROL
}

ChIARA VETTORI EBNER ${ }^{1}$

Institute for Specialised Communication and Multilingualism (Italy)

\begin{abstract}
In the present contribution we discuss the challenges and the results of learning a second language in South Tyrol, the multilingual border region in northern Italy where the autochthonous German- and Ladinspeaking communities have cohabited with the Italian-speaking community since the end of the First World War. The picture resulting from the data collected in the Kolipsi project (Eurac/DiScoF), an extensive linguistic and psychosocial investigation about South Tyrolean secondary school pupils now in its second edition, gives precious inputs to all entities that intervene in the process of attitude formation and change, ranging from the family environment to politics.
\end{abstract}

Keywords: L2 acquisition, CEFR L2 proficiency levels, L2 learning motivation/orientations, intergroup contact.

\section{RESUMEN}

En el presente trabajo, debatimos los retos y los resultados del proceso de aprendizaje de segundas lenguas en el Tirol del Sur, la región fronteriza multilingüe del norte de Italia donde las comunidades autóctonas hablantes de alemán y ladino han convivido con la comunidad italohablante desde el fin de la Primera Guerra Mundial. La imagen resultante de los datos recogidos en el proyecto Kolipsi (Eurac/DiScoF), una investigación abarcadora tanto lingüística como psicosocial sobre alumnado de secundaria del Tirol del Sur, proporciona información muy valiosa a todas las entidades que intervienen en el proceso de la formación y el cambio de las actitudes, desde el entorno familiar hasta el ámbito de la política.

Palabras clave: adquisición de segundas lenguas, niveles de competencia en segundas lenguas del MCER, motivación/orientaciones en el aprendizaje de segundas lenguas, contacto intergrupal.

\section{Introduction}

The aim of this contribution is to illustrate how challenging it is to learn a second language (L2) in a $\mathrm{bi} /$ multilingual context, which should theoretically represent the best possible acquisition milieu, and to what extent attitudes and well-established beliefs can influence this process, be it positively or negatively. The bi/multilingual setting we refer to is the Autonomous Province of Bolzano/Bozen - South Tyrol (South Tyrol for short), a region located in northern Italy bordering Austria and Switzerland. Until 1919 South Tyrol belonged to the Austro-Hungarian Empire which saw its dissolution at the end of the First World War: the signature of the Peace Treaty of Saint-Germain assigned South Tyrol to the Kingdom of Italy, separating it from northern Tyrol, which remained Austrian territory. During the fascist years (1923-1939) which followed the annexation, a strong italianization policy was introduced in South Tyrol, which aimed to foster

\footnotetext{
1 E-mail: maria.lirola@ua.es
} 
the immigration of Italian speakers from other Italian regions. The consequences are still visible today: of the around 505,000 inhabitants, $69.41 \%$ are German speakers, $26.06 \%$ are Italian speakers and $4.53 \%$ are Ladin speakers (ASTAT 2012; Ladin belongs to the Rhaeto-Romanic subgroup within the Romance family and its South Tyrolean speakers mainly reside in two valleys in the Dolomites, Gröden/Gardena and Gadertal/Val Badia).

\subsection{South Tyrol and its historical background}

From a linguistic and cultural standpoint, South Tyrol was deeply marked by the events that followed the annexation. In its attempt to italianize the autochthonous population, fascism not only fostered Italian settlement but, above all, banned the use of the German language at school and in all public domains (cfr. Autonome Provinz Bozen Südtirol 2004, Alcock 2001). Two fundamental achievements were reached by the German-speaking South Tyroleans in the battle for the safeguard of their civil and cultural rights that took place in the following decades: the signature of the Paris Treaty between Austria and Italy (1946) and the Second Autonomy Statute (1972) that still regulates the most important provisions regarding language rights such as linguistic equality, the Ethnic Proportions Decree, the Declaration as to Linguistic Origin and the bilingualism examination. According to the Autonomy Statute, the German language is equal in every aspect to the Italian language (Article 99) and "German-speaking citizens of the Province of Bolzano/Bozen have the right to use their own language in relations with the judicial offices and with the organs and offices of the public administration" (Article 100) (cfr. Autonome Provinz Bozen-Südtirol 2006). Children are educated in their mother tongue by mother tongue teachers and attend separate schools according to linguistic group; second language learning, Italian or German, is compulsory in both primary and secondary schools. The principle of ethnic proportion reflects the fact that the positions in public offices are filled according to the numerical strength of the language groups living in South Tyrol which is determined via the census carried out every ten years, whereby each citizen must declare himself/herself as belonging to one of the three major language groups.

To guarantee that everyone can use his/her mother tongue when dealing with public offices, in 1976 the bilingualism examination was introduced as a precondition for recruitment into the public sector. The examination, consisting of a written (listening comprehension and written production) and an oral test, should ascertain the candidates' bilingual proficiency as it must be taken in both languages, i.e. German and Italian, in one of four degrees of difficulty (from D to A), each according to the school qualification needed to apply for different careers in the public sector (cfr. Autonome Provinz Bozen Südtirol 2016, Abel/Vettori/Forer 2012).

\section{The current linguistic situation}

In spite of the fact that South Tyrolean educational system provides separate "monolingual" schools for each one of its three language groups ${ }^{2}$, it is also strongly concerned with second language instruction. As a matter of fact, from the first to the thirteenth school year (age 6 to 19) L2 learning is compulsory and comprises more than 2,000 teaching lessons for both German and Italian-speaking pupils (cfr. Egger 2001: 163). Moreover, second language instruction is also promoted by a wide range of special measures such as study trips, partnerships with German/talian-speaking schools and CLIL (Content and Language Integrated Learning) teaching. Nevertheless, despite the considerable resource costs and the many initiatives, L2 proficiency of South Tyroleans - and especially that of Italian speakers - is widely believed to be inadequate. Findings of past investigations regarding L2 competences as well as the results of the bilingualism examination all point to a relatively low $L 2$ proficiency of the South Tyrolean population (cfr. Putzer 1997a/b; Deflorian 1997; Vettori 2005; Astat 2006a/b). The data from the bilingual examination sessions in 2014 show that only half of the candidates passed the examination $A^{3}$, while just $44 \%$ of those who took the B examination passed (ASTAT 2015).

\footnotetext{
2 In primary schools and in the first grade of secondary schools (age 6 to 11 and 11 to 14 years), Ladin speaking pupils are taught in three languages, Ladin, German and Italian, and then opt either for a German or an Italianspeaking second grade secondary school (age 14 to 19).

${ }^{3} \mathrm{~A}$ : the level necessary for every job in the public administration that requires a university degree; $\mathrm{B}$ : the level necessary for every job in the public administration that requires a second grade secondary school qualification.
} 
Neither the schools' efforts nor the physical proximity of the two groups seem therefore sufficient to produce the multilingual society one would expect in such circumstances; on the contrary, literature and observers of local everyday life (cfr. Egger 2001; Lanthaler 2006) speak of separate linguistic sub-groups which do not share contacts with each other and where "the language of the other is learned as if the other lived in a far away, unreachable country" (Baur 2000: 300). However, South Tyrol is not an exception. In fact, this is a well known phenomenon in regions where different linguistic groups live together and where bilingualism and interculturality are not per se taken for granted and do not normally develop on large scale, as shown by the situation described in Switzerland and in the region on the border between Germany and Denmark (Baur \& Mezzalira \& Pichler 2008: 35). The same thing also happens in Canada where, after twelve years of learning French, English-speaking pupils are not sufficiently competent to speak in their L2 with French-speaking Canadians (Baker 2006: 224).

It is evident that becoming bilingual in South Tyrol - and also in other regions - involves a series of sociolinguistic and psycho-social issues such as attitudes, prejudices, contact and speaking habits, level of motivation etc. that cannot be ignored by the entities involved in $L 2$ teaching nor by second language acquisition researchers. As Ushioda (2010: 16) illustrates with great clarity, "in an inherently social process such as language acquisition, the person cannot be meaningfully separated from the social environment within which he/she operates, and so the challenge is to adopt a dynamic perspective that allows us to consider simultaneously the ongoing multiple influences between environmental and individual factors, in all their componential complexity, as well as the emerging changes in both the person and the environment.

\section{The Kolipsi project}

The aspect of our innovative research project that we believe to be most positive is the consideration of both the linguistic and the extra-linguistic aspects of L2 learning in South Tyrol in our study. In 2007, after a first explorative study conducted on a sample of Italian pupils (Vettori 2005) which also emphasized the absence of large scale empirical studies regarding the L2 proficiency in the province of Bolzano, the European Academy of Bolzano/Bozen (EURAC) and the Department of Cognitive Science and Educational Sciences at the University of Trento (DiSCof) started an interdisciplinary project whose aim was to describe the L2 competences (Italian/German) of a representative sample of attendants of second grade secondary schools and, at the same time, to identify extra-linguistic factors that influence their L2 competence levels. The first edition of the project called "KOLIPSI. South Tyrolean pupils and the second language: a linguistic and socio-psychological investigation" (Abel/Vettori/Wisniewski, 2012) proved to be a precious instrument, above all for politics, and at the end of 2013 the same project partners finally obtained the funds to start a second edition.

Considering the status quo previously described, we adopted the concept of L2 communicative language competence envisioned in the Common European Framework of Reference (CEFR; Trim/North/Coste 2001: 9-13). The CEFR takes an action-oriented approach that views "users and learners of a language primarily as 'social agents', i.e. members of society who have tasks (not exclusively language-related) to accomplish in a given set of circumstances, in a specific environment and within a particular field of action" (ibid., 9). We thought that such an approach would best suit our purpose to look at what South Tyrolean pupils really can do in their L2 in a series of written and oral tasks, which could potentially occur in their everyday life. To this end, we developed a writing and an oral test ad hoc, in collaboration with the Herder Institute in Leipzig, to assess the productive and interactive competences for different aspects of the L2 according to CEFR reference levels for the very first time in South Tyrol. At the same time, we invested great efforts in investigating the extra-linguistic aspects with qualitative ${ }^{4}$ and quantitative survey techniques.

\footnotetext{
${ }^{4}$ In the first edition of the project, we conducted a series of interviews with "privileged observers", sixteen key figures from South Tyrolean life, and focus groups with pupils the same age as those participating in our study, in order to identify the topics for the questionnaires.
} 


\subsection{Sample and data collection tools.}

In the first edition of the project, we collected data for a representative sample consisting of around 1,300 17-18 year old fourth grade pupils from all secondary schools in the Province (school year 2007/2008). In the present edition (school year 2014/2015) we reached around 1,600 pupils; in both cases the sections involved were randomly selected. Our targets are South Tyrolean pupils with Italian and German backgrounds, therefore Ladin-speaking pupils or pupils with migrant backgrounds are not included in the analysis. Besides the pupils, we also involved their parents and L2 teachers as we also submitted an extensive questionnaire to them so as to gain the most detailed insight possible regarding the opinions, attitudes and behaviour not only of secondary school attendants but also of those with whom they live and from whom they learn.

The core of the linguistic part of the study is the KOLIPSI writing test, which in both cases was followed by another written test ${ }^{5}$. It consists of writing an e-mail to a friend to tell him a story based on four pictures provided in the assignment, and a letter to a friend to organise the next summer holidays by the sea or in the mountains. In this latest edition, we substituted the second task with a new one: pupils were asked to write an e-mail to a boy who had written a letter to a magazine asking for advice. The range of competences targeted for these tasks lay around B1/B2. However, since we were aware that not all performances would lie within this range, we also included the upper and lower levels in the assessment grid (i.e. A2/A1 and C1/C2).

Concerning the psychosocial part, numerous topics were addressed in a comprehensive questionnaire study, such as demographic, cultural and social characteristics of the target population, external and selfevaluation of L2 skills, L2 use habits, L2 confidence, L2 learning motivation, attitudes toward the language groups, linguistic identity, relative deprivation feeling and ethnolinguistic vitality.

\section{The results}

Quite a remarkable difference between the two language groups emerges from the Kolipsi test (cfr. Graph 1 and 2) ${ }^{6}$. Almost half of both samples reaches level B1 of the CEFR (German speakers 44\%, Italian speakers $47 \%$ ). However, whereas $40 \%$ of the German speaking Italian learners achieve level B2 (and 11\% level C1), almost one third of the Italian speaking German learners remains at level A2 (28\%), with only a small percentage performing better ( $13 \%$ level B2, $5 \%$ level C1). Among a number of possible influencing factors on these results, namely school type, gender and language environment (i.e. the presence of L2 group people in one's environment), the type of school pupils attend turned out to play an important role, emphasising the lower performance of pupils who attend a technical secondary school (istituto tecnico/Fachoberschule) as compared to those who attend an academic secondary school (liceo/Gymnasium).

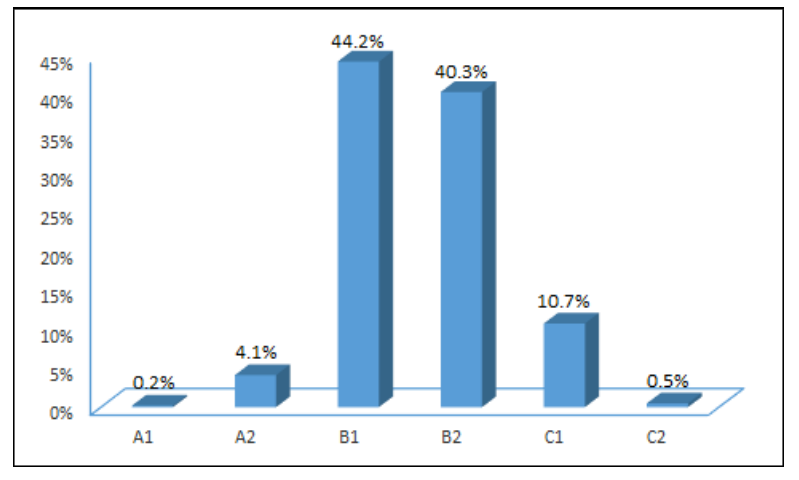

\footnotetext{
5 In 2007/2008 pupils answered questions in their L2 about a text in their L1 taken from the South Tyrolean bilingualism examination, while in 2014/2015 they completed a listening comprehension and a vocabulary test (DIALANG).

${ }^{6}$ The linguistic and psycho-social data collected during the school year 2014/2015 are still being analyzed, therefore we will present the results of the $2007 / 2008$ sample.
} 
Graph 1. KOLIPSI writing test results: German-speaking pupils with Italian L2

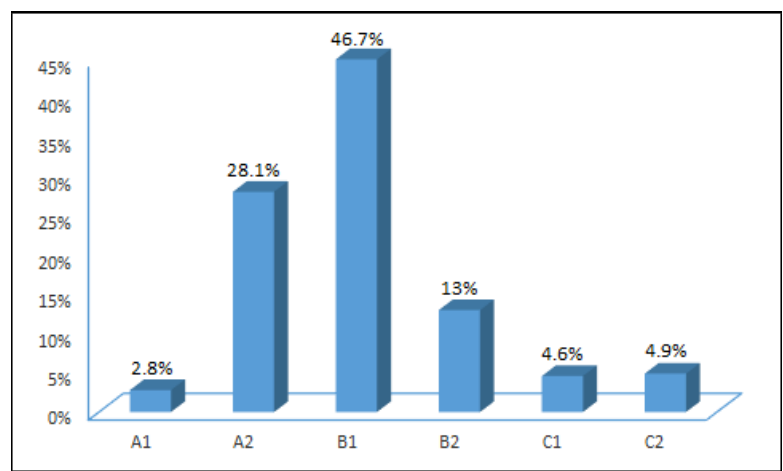

Graph 2. KOLIPSI writing test results: Italian-speaking pupils with German L2

Though it has proven to be a strong predictor of $L 2$ proficiency, school type cannot be the only reason for such a set of results. As a matter of fact, the decisive role of extra-linguistic factors on L2 acquisition in South Tyrol is clearly shown by the results of our conjoint study. In spite of the enormous amount of L2 teaching hours per year and regardless of individual characteristics, the key to interpreting the L2 performance of South Tyrolean pupils must be searched for beyond school walls. Analysing the peculiar situation in South Tyrol, we thought that two aspects could heavily influence the L2 acquisition process more than others, namely contact with L2 group members and level of motivation. International studies have declared contact a fundamental factor in promoting positive attitudes between groups ${ }^{7}$, while motivation has been a major research topic since Lambert and Gardner's studies in the 70s, and it can be hardly denied that "being motivated or not can make all the difference to how willingly and successfully people learn other languages later in life" (Ushioda 2010: 5).

\subsection{Contact and L2 learning motivation.}

In spite of general beliefs, the survey showed that South Tyrolean pupils do have contacts with their L2 peers and with L2 people in general. A large majority of our sample have at least some friends in the other language group and those who have never or only very rarely had a relation of friendship with members of the other group live mainly in areas in which the L2 group is very small in numbers or is at least in the minority. The simple fact of having a friend from the other language group is sufficient to produce a more positive attitude toward this group (cfr. Graph. 3). This is also true for those with experience of extended intergroup contact (Wright et al. 1997), that is those whose friends and/or family members maintain friendships with people from the other language group. In addition, this latter group shows more positive attitudes toward the other language group.

\footnotetext{
${ }^{7}$ Cfr. Pettigrew/Tropp 2006, Wright 2009.
} 


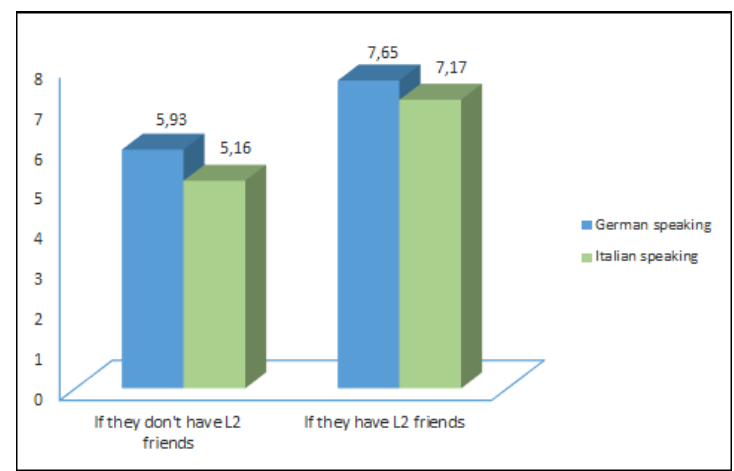

Graph 3. Attitude toward L2 Language Group According to Contacts between Language Groups for German- and Italian-speaking Pupils in South Tyrol (scale from 1 to 10).

Investigating the attitude toward the $L 2$ group is strategical especially from a motivational perspective. Gardner (2007: 10) defines L2 learning motivation as a synthesis of three elements: the effort put in to learn the language, the desire to learn it and the positive effect toward the task itself. Strictly connected to motivation are the so-called orientations that, in Gardner's theory, "help arouse motivation and direct it towards a set of goals" (Dörnyei/Ushioda 2001: 41) and that can be labelled as either integrative or instrumental. In the first case, the L2 learner has a positive disposition toward the L2 group and he desires to communicate with its members and even become similar to them; in the second, he thinks merely of the pragmatic gains of $L 2$ proficiency, for example for his working life, without implying any interest in getting closer socially to the language community (Masgoret/Gardner 2003: 129). In the case of South Tyrolean pupils, we found that L2 proficiency correlates positively with motivation and with integrative orientation but not with instrumental orientation ${ }^{8}$. This also means that having a positive attitude toward the other group may sustain L2 learning motivation but also that although the vast majority of the sample resolutely states that studying the L2 is important for pragmatic reasons, it is not this type of goal that can effectively help in achieving good $\mathrm{L} 2$ results.

The latter deduction put into discussion the entire L2 learning system in South Tyrol based on the separation of the two groups and indirectly fostering the idea that it is possible to learn a second language at school without coming into contact with and speaking to L2 people. It also contradicts the many parents who spur on their children to learn German/talian just for the purpose of passing the bilingual examination. Underlining the pragmatic benefits of mastering the $L 2$ does not contribute to improving the pupils' competences at all: on the one hand because of its short-term urgency (i.e. the pending bilingual examination, conditio sine qua non for getting a job in the public sector - traditionally seen as the most stable -), on the other hand because of its long-term target, as the majority of the pupils usually go to university before getting out onto the job market $(58.7 \%$ of all secondary schools graduates in 2013 , ASTAT 01/2016). Moreover, this generalized focus on the practical benefits of mastering the L2 pushes the integrative motives into the background, undermining and even neglecting the social dimension of learning a second language which, by definition, "plays an institutional and social role in the community" (Ellis 2002: 12). It is no coincidence that second language learning differs from foreign language learning which "takes place in settings where the language plays no major role in the community and is primarily learnt only in the classroom" (ibid.).

\section{Conclusions}

The data we presented show how the extra-linguistic factors, in particular intergroup contact and motivation, deeply influence L2 learning outcomes in South Tyrol. The school type has also proven to be

\footnotetext{
8 Data refer to a subsample of 734 pupils who answered all questions about their L2 learning motivation and orientations. Motivation $\left[r_{(592, G E R)}=.278^{* *}, p<.001, r_{(142, I T A)}=.328^{* *}, p<.001\right]$, integrative orientation $\left[r_{(590, \text { GER })}=\right.$ $\left..163^{* *}, p<.001 ; r_{(140, \text { ITA })}=.330^{* *}, p<.001\right]$, instrumental orientation $\left[r_{(585, \text { GER })}=.051, p=.216, r_{(140, I T A)}=.077, p=\right.$ .367]. For an extensive description of the analysis carried out cfr. Vettori 2012.
} 
an influential factor, whereby pupils attending a technical secondary school show L2 competences that are clearly below those observed in academic secondary schools. However, it is not possible to determine whether the school curriculum or the personal attitudes of pupils themselves lie behind this status quo. It can be hypothesized that the pupils' preference toward technical subjects as opposed to humanities and the proportion among these two subject areas which, in technical secondary schools is decidedly unbalanced in favour of technical subjects, both contribute to the pupils' lower L2 competences. It would be interesting and, in our opinion, necessary to further investigate the attitudes, beliefs and habits of the technical secondary school attendants as well as the L2 programs applied, in order to put forward an explanation of the phenomenon and possible suggestions for improving the situation.

Nobody can deny that school plays a crucial role in L2 learning, however our analysis has clearly highlighted the role of what happens outside the school walls. The promotion of intergroup contact is crucial for both fostering a better understanding and increased mutual feeling of openness and friendliness between the groups and for experiencing the L2 in a real context. The tendency to consider school as the only occasion where the L2 can be acquired, most typical for the Italian speaking community (cfr. Giudiceandrea 2006: 23-37), needs to be changed. As a matter of fact, placing excessive emphasis on the role of the school in L2 learning without considering the influence of extra-linguistic factors put L2 teachers in a difficult position and stirs up the ever-recurrent debate about $L 2$ teaching methods, always in search of the best ever approach. The attempt by the Italian-speaking schools to introduce the Content and Language Integrated Learning method that dates back to the 1990s and which- after decades of polemics and legal struggles - has only recently been officially ratified for both the Italian and the German-speaking schools (cfr. BU n. 29/I-II of 16/07/2013, BU n. 27/I-II of 08/07/2014 and BU n. 5/I-II of 02/02/2016), is the most evident demonstration of the generalized approach to the topic in South Tyrol.

As we do not yet have extensive empirical data demonstrating the benefits of CLIL in South Tyrol at our disposition and on the basis of our research, we think it would be fruitful to consider language learning a social process (cfr. Firth/Wagner 2007) and to promote intergroup contact. The L2 teachers could introduce the pupils to the culture of the L2 group, encouraging the reading of local authors and helping them to get familiar with the local press. Schools should further promote exchanges between the German and the Italian-speaking schools through, for example, the already existing possibility of attending the fourth year of the secondary school in the L2 school. Politics should grant teachers the opportunity to attend teacher training courses and should economically sustain public and private initiatives that bring German and Italian-speaking young people together, such as sport and music courses, parties, summer camps and others. Besides that, politics should also promote the regular monitoring of language competences and of extra-linguistic aspects in order to check if the route taken is the right one and, if not, to take corrective action.

Finally, parents should demonstrate their openness toward the L2 community and, above all, encourage their children to get in contact with their L2 peers, convincing them that good L2 proficiency is more important for their current presence in the South Tyrolean community than for their future job. This could reinforce their integrative orientation, stimulating them to search for contact with the L2 community and thereby opening them up to "a whole dimension of motivational experience that is crucial to autonomous language learning - that is, the experience of language use, and all the positive motivational repercussions, self-perceptions and intrinsic rewards that using the language can bring" (Ushioda 1996: 31).

\section{References}

Abel, A., Vettori, C., Forer, D. (2012). Learning the Neighbour's Language: the Many Challenges in Achieving a Real Multilingual Society. The Case of Second Language Acquisition in the MinorityMajority Context of South Tyrol. In European Centre for Minority Issues \& European Academy Bolzano/Bozen (eds.) European Yearbook of Minority Issues, Vol. 9. Leiden: Brill Academic Publishers, pp. 271-304.

Abel, A. \& Vettori, C. \& Wisniewski, K. (eds) (2012). Die Südtiroler Schülerlnnen und die Zweitsprache: eine linguistische und sozialpsychologische Untersuchung. Bolzano/Bozen: Eurac. 
Alcock, A. (2001). The South Tyrol Autonomy. A Short Introduction. County Londonderry Bozen/Bolzano. http://www.provincia.bz.it/news/de/publikationen.asp?publ_action=4\&publ_article_id=1588

ASTAT (2012). Astat info 38. Bozen: Autonome Provinz Bozen. Bolzano/Bozen: Autonome Provinz Bozen

ASTAT (2015). Südtiroler Sprachbarometer. Sprachgebrauch und Sprachidentität in Südtirol. Bolzano/Bozen: Autonome Provinz Bozen.

ASTAT (2016). Astat info 01. Bolzano/Bozen: Autonome Provinz Bozen.

Autonome Provinz Bozen Südtirol (ed.) (2004). Südtirol Handbuch. (23. Aufl.). Bolzano/Bozen: Landespresseamt.

Autonome Provinz Bozen-Südtirol (2016). L'esame di bilinguismo. Atmhttp://www.provincia.bz.it/ebt/temi/esame-di-bilinguismo.asp

Autonome Provinz Bozen-Südtirol (ed.) (2006). Das neue Autonomiestatut. Bolzano/Bozen: Landespresseamt.

Baker, C. (2006). Foundations of bilingual education and bilingualism. IVth ed. Clevedon: Multilingual Matters.

Baur, S. (2000). Die Tücken der Nähe: Kommunikation und Kooperation in MehrheitsMinderheitssituationen. Meran: Alpha Beta.

Baur, S., Mezzalira, G., Pichler, W. (eds.) (2008). La lingua degli altri. Aspetti della politica linguistica e scolastica in Alto Adige-Südtirol dal 1945 ad oggi. Milano: FrancoAngeli.

Deflorian, F. (1997) (unpublished). Considerazioni riassuntive sui risultati delle prove nella comprensione scritta e orale, nella produzione scritta e nella produzione orale della lingua seconda degli alunni delle ultime classi della scuola elementare, media e superiore in lingua tedesca. Bolzano/Bozen: Provincia Autonoma di Bolzano/Bozen, Ufficio Bilinguismo.

Dörnyei, Z., Ushioda, E. (2011). Teaching and Researching Motivation. 2nd edition. Halow, Essex: Longman.

Egger, K. (2001). Sprachlandschaft im Wandel: Südtirol auf dem Weg zur Mehrsprachigkeit; soziolinguistische und psycholinguistische Aspekte der Ein- und Mehrsprachigkeit. Bozen: Athesia.

Ellis, R. (2002). The Study of Second Language Acquisition. Oxford: Oxford University Press.

Firth, A., Wagner, J. (2007): Second/Foreign Language Learning as a Social Accomplishment: Elaborations on a Reconceptualized SLA. The Modern Language Journal, Vol. 91, Issue Supplement s1, pp. 800-819.

Gardner, R. C. (2007). Motivation and Second Language Acquisition. Porta Linguarum 8, pp. 9-20.

Giudiceandrea, L. (2006). Spaesati. Italiani in Südtirol. Bolzano/Bozen: Raetia.

Lanthaler, F. (2006). Die Vielschichtigkeit des Deutschen in Südtirol. In Abel, A., Stuflesser M., Putz, M. (eds.) Mehrsprachigkeit in Europa: Erfahrungen, Bedürfnisse, gute Praxis. Atti del convegno (Bolzano, 24-26 agosto 2006), Bolzano/Bozen: Eurac.

Masgoret, A. M., Gardner, R. C. (2003). Attitude, Motivation, and Second Language Learning: A MetaAnalysis of Studies Conducted by Gardner and Associates. Language Learning 53:1, pp. 123-163.

Pettigrew, T. F., Tropp, L. R. (2006). A Meta-analytic Test of Intergroup Contact Theory. Journal of Personality and Social Psychology 90, pp. 751-783. 
Putzer, O. (1997a) (unpublished). Zusammenfassende Analyse und Ergebnisse der schriftlichen Sprachfertigkeiten an den italienischen Oberschulen, Mittelschulen und Grundschulen. Bozen: Autonome Provinz Bozen - Amt für Zweisprachigkeit.

Putzer, O. (1997b) (unpublished). Zusammenfassende Analyse und Ergebnisse der mündlichen Sprachfertigkeiten an den italienischen Oberschulen, Mittelschulen und Grundschulen. Bozen: Autonome Provinz Bozen - Amt für Zweisprachigkeit.

Trim, J., North, B., Coste, B. \& al. (2001). Common European Framework of Reference for Languages (CEFR). At http://www.coe.int///dg4/linguistic/Source/Framework_EN.pdf

Ushioda, E. (1996). The role of Motivation. Dublin: Authentik

Ushioda, E. (2010). Motivation and SLA. Bridging the gap In Roberts, L., Howard, M., Ó Laoire, M., Singleton D. (eds.) EUROSLA Yearbook, Vol. 10. Amsterdam: John Benjamins. pp. 5-20

Vettori, C. (2005) (unpublished). La competenza del tedesco degli studenti italofoni di scuola media inferiore e superiore di Bolzano e Trento: confronto e valutazione. PhD dissertation, University of Modena and Reggio Emilia.

Vettori, C. (2012). L'apprendimento della seconda lingua in Alto Adige: orientamenti e motivazione. Contesto e criticità. In Abel, A., Vettori, C. Wisniewski, K. (eds.) Die Südtiroler Schülerlnnen und die Zweitsprache: eine linguistische und sozialpsychologische Untersuchung. Bolzano/Bozen: Eurac.

Wright, S. C. (2009). Cross-Group Contact Effects. In Otten, S., Kessler, T. y Sassenberg K. (eds.). Intergroup Relations: The Role of Motivation and Emotion. New York: Psychology Press, pp. 243261.

Wright, S. C., Aron, A., McLaughlin-Volpe, T. y Ropp, S. A. (1997). The Extended Contact Effect: Knowledge of Cross-Group Friendships and Prejudice. Journal of Personality and Social Psychology 73, pp. 73-90.

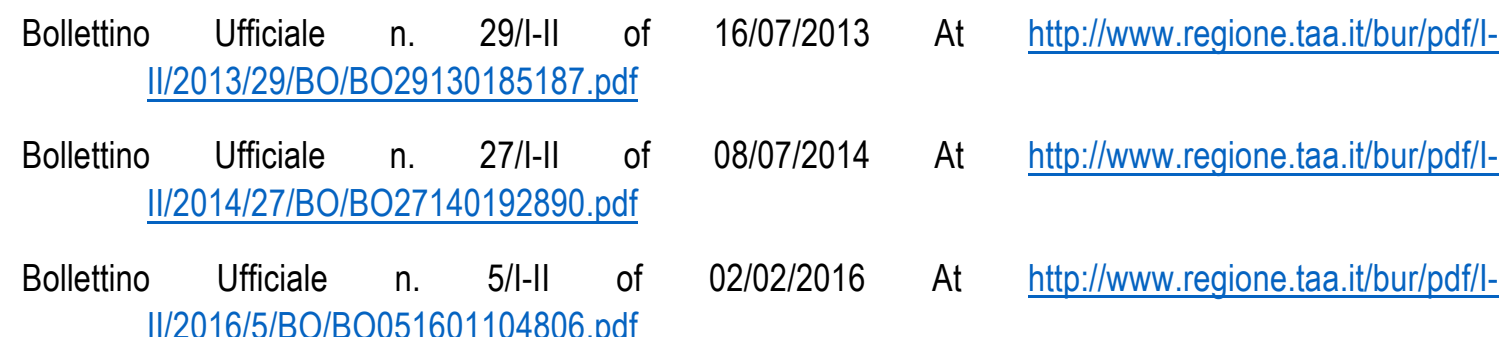

Received: 02/03/2016

Accepted: 24/06/2016 